\title{
M. MACKEPRANG
}

\author{
af Axel Linvald.
}

Efter en arbejdsdag, som havde varet længere, end der er beskåret de fleste mennesker, gik vort Nationalmuseums $\emptyset$ verste leder 1922 (1910)-38 M. Mackeprang bort 8. marts 1959, knapt @0 år gammel. Halvandet år f $\phi \mathbf{r}$ han døde kunne han lejlighedsvis tale om den inertiens lov «, der gjorde det vanskeligt for ham at tage fat på noget *); i virkeligheden var det dog først nogle uger forinden hans $d \varnothing d$, da synet svigtede, at han mistede arbejdsmodet. I vor fortravlede tid havde han aldrig travlt. Måske netop derfor fik han udrettet så meget.

Bortset fra en lille eskapade under skoletiden i Sor $\varnothing$ — da han som frivillig lærling i marinen var på togt i Middelhavet - har Mackeprang altid villet være historiker. I studieårene, som 1894 afsluttedes med en magisterkonferens, påvirkedes han særlig af Kr. Erslev, der netop i de år blev den store vakker og opdrager af et rigtbegavet kuld af unge historikere. 1895-97 fortsatte han Moltesens studier i Vatikanarkivet. I nogle efterladte selvbiografiske optegnelser lægger han ikke skjul på, at det gennemgåede materiale syntes ham lidet frugtbart, og han benyttede det da heller ikke til den disputats, der åbenbart havde foresvævet ham. I stedet for, skriver han, sstuderede han Rom og modtog uudslettelige indtryk af verdenshovedstadens historiske og kunstneriske rigdomme. Mackeprang gav sjældent stærke udtryk for sine følelser. Nedskriveren af disse linier, der en måned igennem cn gang i 1930'erne færdedes sammen med ham i Rom kunne dog ikke undgå at mærke ungdomsoplevelsernes styrke. Efterladte breve vidner også om hans glæde ved at mindes bes $\emptyset \mathrm{g}$ i Firenze og Toscanas småbyer, hvor han havde taget ferie fra sliddet i Vatikanarkivets protokolmasser.

*) Denne artikels forfatter benytter samme forklaring på og undskyldning for, at den fremkommer så længe efter Mackeprangs $d \varnothing d$. 
Faget vælger man af interesse; stillingen skyldes i reglen tilfældet. Således gik det også Mackeprang. Oprindelig havde han håbet på en ansættelse i Rigsarkivet; da der ingen plads var ledig, gik han ind i Nationalmuseet. Det er ikke stedet her udf $\varnothing$ rligt at skildre hans indsats i dets tjeneste. Som enhver anden har han mødt vanskeligheder og haft sine skuffelser. De største besværligheder skyldtes vel arbejdet med Nationalmuseets byggesag. Efterverdenen vil antagelig d $\varnothing \mathrm{mme}$, at det var en lykke, at han ikke havde held til at gennemf $\phi r e ~$ Kastelsplanen «. Selv har han også anerkendt, at løsningen, som blev resultatet af mange og lange forhandlinger, var den bedste. Havde man i 1917 sagt ham, at der var mulighed for, at museet skulle komme til at råde over hele kareen mellem Frederiksholms Kanal og Vestervoldgade, har han skrevet, »vilde jeg ubetinget have slået til straks. Men det forelå nu ikke, og et Forslag herom vilde dengang være bleven betragtet som uhyrligt. At jeg af opportune Grunde ofte er gået videre, end det nok var heldigt, er en Sag for sig, men her som så ofte har Lykken været bedre end Forstanden «.

Når det gik, som det wjorde, skyldtes det »de fem store«, hvis bistand blev påkaldt $i$ det rette $\varnothing$ jeblik.

Meget andet burde nævnes, som hører med i billedet af Mackeprangs indsats som historiker og museumsmand: Foruden disputatsen fra 1900 om dansk Købstadsstyre fra Valdemar Sejr til Christian IV, Kirkeværket, som han gav dets start, hans afhandlinger og bøger om vore landsbykirker 1920 (2. udg. 1944), om middelalderlige døbefonter (1941), om jyske granitportaler (1948) og om Kronborg-tapeterne (1950) for slet ikke at tale om de store af snit, han har skrevet til værket om Sorø, Klostret, Skolen og Akademiet gennen tiderne. Navnlig Mackeprangs betydning for Nationalmuseet burde nok have været anerkendt af Det danske Videnskabernes Selskab som udtryk for, at man også kan tjene videnskaben på anden måde end ved at skrive bøger. Ganske hortset fra, at hans mange og værdifulde videnskabelige arbejder, skrevet og udgivet efter hans fyldte $\mathbf{7 0}$ år, understreger, hvor urimeligt det er for et videnskabeligt selskab faktisk at opretholde en formel aldersgrænse.

Sandheden i ære må det tilføjes, at selskabet viste ham en sen honn $\phi r$ - i 1955 - ved at tildele ham sin guldmedaille. 


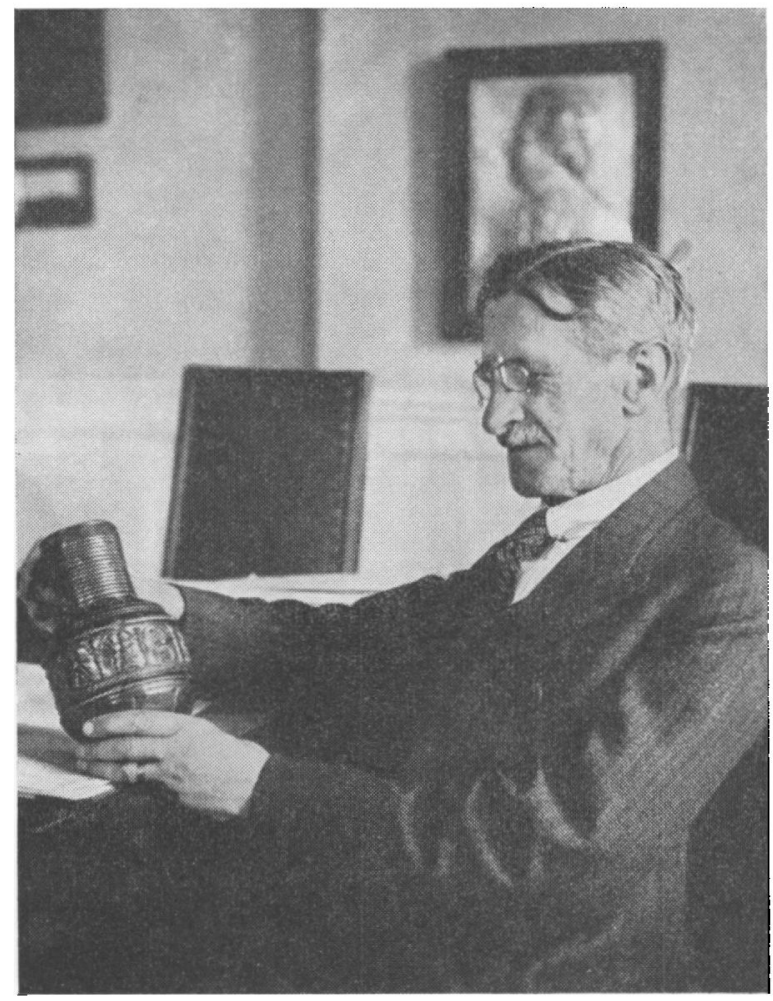

Mackeprang var nordslesviger. Om ham — så vel som om hans ægtefælle, Ingeborg $\mathrm{f}$. Winther, fra Haderslev - gjaldt det, at de livet igennem bevarede karaktertrækkene, der f $\varnothing$ les som særlige for de danske nordslesvigere: Styrken i karakteren, trofastheden, de stille, men stærke følelser, som undviger store ord og netop derfor virker stærkere. Livet igennem og stadig mere, som årene gik, følte Mackeprang sig knyttet til sin nordslesvigske hjemstavn. At denne artikel er skrevet til Sønderjyske årbøger g $\phi r$ det naturligt, at den $i$ særlig grad fremhæver hans gerning $i$ Nordslesvigs tjeneste. Af æresbevisninger, som er blevet ham til del, tror jeg at turde sige, var der næppe nogen, som glædede ham mere, end at han blev æresmedlem af »Historisk samfund for Sønderjylland«. Han har vistnok heller ikke fors $\varnothing \mathrm{mt}$ noget 


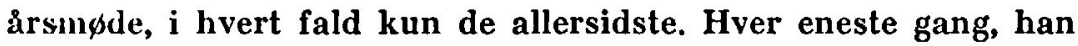
var med til et af dem, er det fortalt mig, tog han også ned til f $\emptyset$ degården, Kiding i Felsted sogn, ville ikke ind i huset, men gik i tavshed rundt om det. Nordslesvigs interesse var da også den eneste, der kunne bevæge ham til at bryde sit princip efter afgangen fra direkt $\varnothing$ rstillingen ikke at ville påvirke efterf $\varnothing$ lgeren. *Endelig «, har han en gang i 1950 skrevet til mig, shar jeg fåt Nørlund til at tage fat på det nordslesvigske Bind af Danmarks Kirker «. Selv tog han ogssa sin del af arbejdsbyrden på sig og sled sig ufortrødent gennem de mange kirkeregnskaber.

Fra f $\phi$ rste færd h $\phi$ rte Mackeprang med i den lille, men indflydelsesrige kreds, der samledes $i$ den nu helt glemte forening med det mærkelige navn $\gg 4 S_{\ll}:$ Studenter-Samfundets $S \emptyset$ nderjyske Samfund ${ }^{*}$ ). Initiativtageren til dets stiftelse (1887) var Johan Ottosen. Sålænge han levede, var $H$. P. Hanssen bestemmende for kredsens anskuelser. Árene igennem var professor Harald $H \phi f f d i n g$ foreningens formand, og Georg Brandes dens største og mest glansfulde navn. Som bestyrelsens Benjamin - og formand for 4 S's studenterafdeling $\gg$ Vidar — har den, der skriver disse linier, allerede i sine første studenterår modtaget uudslettelige indtryk af kredsens mænd, deres idealitet, omfattende viden og levende optagethed af alle nordslesvigske anliggender. Ledende $i$ arbejdet var de tre historikere, livet igennem nære venner: H. V. Clausen, Aage Friis og Mackeprang. H. V. Clausen var nok den iderigeste, Aage Friis den stærkeste vilje, Mackeprang måske den klogeste. Uden denne kreds og dens forbindelser i den politiske verden havde det næppe været muligt at gennemføre den løsning af vort grænsespørgsmål, som blev resultatet.

Indtil krigsudbruddet i 1914 var Mackeprang efter A. D. J $\emptyset$ rgensens d $\varnothing d$ i 1897 - en tid sammen med Aage Friis - den vir-

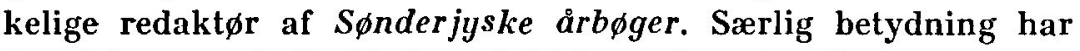
den kloge og indholdsrige skildring af nationalitetskampen $i$ Nordslesvig 1864-1909, som han udgav i 1910. Ikke mindst på baggrund af de bitre modsætninger mellem $H$. P. Hanssen og

-) Den lille forening, hvis medlemstal holdt sig omkring de 300, ophævedes efter genforeningen. Dens historie er 1921 skrevet af chefen for det kongelige Bibliotek, overbibliotekar Carl S. Petersen i Politikens kronik. 
Jessen var det en bedrift at skrive denne bog, uden at den vakte deres mangeårige strid til nyt liv. Med rette har Carl S. Petersen gjort opmærksom på, at bogen, der også udkom i tysk oversættelse 1912, sammen med den franske bearbejdelse af Franz von Jessens håndbog i det nordslesvigske spørgsmåls historie (1906), har været en hovedkilde for udlandets kendskab til de nationale forhold i Slesvig.

I en mindeartikel om Mackeprang er der særlig grund til at nævne de smukke ord, hvormed han sluttede bogens fortale:

»Der er vel mangen Nordslesviger, der senere bittert har fortrudt, at han som 16-17 Aars Dreng valgte at gaa mod nord, har folt det, som var han flygtet fra sin Del af Arbejdet. Maatte da denne Bog blive taget for god som en Rømningsmands Haandsrakning til dem, der blev dernede".

Tysklands sammenbrud i den f $\varnothing$ rste verdenskrig i 1918 blev indledningen til det mest bevægede år $\mathbf{i}$ Mackeprangs liv. En måneds tid inden afslutningen var han med $i$ forberedelsen af afstemningen i forste zone; senere under den voldsomme meningskamp $i$ anden zone var han tilforordnet den internationale kommission i Flensborg. Om disse episoder har Mackeprang skrevet til mig, at han i Haderslev var blevet brugt »som $\mathbf{H j æ l p e d r e n g}$ under Agitationen «. 1 Flensborg, erklærer han, havde han været »aldeles unyttig«. Om det er rigtigt er dog vist mere end tvivlsomt; i hvert fald ved jeg, at han havde forstået på et afgørende sted at gøre sin opfattelse galdende.

Citaterne er udtryk for Mackeprangs beskedenhed og uhøjtidelighed; $i$ al sin gerning hørte han til de fă, som snarere gjorde sig mindre, end han var. Der fandtes dem, som ikke forstod denne side af hans vasen; af og til er den måske også kommen ham til skade. For dem, der har stået ham nær, var det egenskaber, som forøgede hans menneskelige værd. 